\title{
Organic Vegetable Production in California-Science and Practice
}

M ark Gaskell, ${ }^{1}$ Benny Fouche, ${ }^{2}$ Steve Koike, ${ }^{3}$ Tom Lanini, ${ }^{4}$ J eff M itchell, ${ }^{5}$ and Richard Smith ${ }^{6}$

ADDITIONAL INDEX WORDS. sustainable agriculture, alternative agriculture

Summary. This article summarizes the current status of organic vegetable production practices in C alifornia. The production of vegetables organically is growing rapidly in California, led in large part by growth in the market demand for organically grown produce. Key aspects of organic vegetable production operations such as certification and farm production planning, soil management, weed management, insect management, and plant disease management involve special practices. Many practices have not been thoroughly researched and the scientific base for some practices is still being developed.

O

rganic vegetable production in California has increased during the 1990s led in large part by expanding nationwide demand for organically grown fresh fruits and vegetables. O rganic vegetables from California also are increasingly being exported to growing overseas markets. In 1995, registered California organic fruit and vegetable growers produced farm gate sales in excess of $\$ 95$ million from 1452 farms. By 1998 the number of registered farms had grown by nearly $60 \%$ to an estimated 2300 (Tourte and Klonsky, 1998). These statistics are conservative however, as estimates suggest that the volume of fruit and vegetables coming from registered organic operations may be only $30 \%$ to $40 \%$ of the total volume of produce grown organically in the state (Tourte and Klonsky, 1998).

O rganic agricultural operations have special needs for production, planning and management beyond those of conventional farms because of limitations imposed by organic registration and certification. $\mathrm{N}$ ew legislation may eventually establish national standards, which will require certification by aU SD Aapproved certifying agency. Currently, registration is a legal requirement for sale of organic produce in California and certification is a private, independent process used by growers and marketers to maintain the integrity of the organic product in the marketplace. Clearly, organic vegetable production is expanding to meet the needs of a growing market but the expansion is taking place on a very limited scientific research base.

The cost of publishing this paper was defrayed in part by the payment of page charges. U nder postal regulations, this paper therefore must be hereby marked advertisement solely to indicate this fact.

${ }^{1}$ Farm advisor, U niversity of California Cooperative Extension, 624 West Foster Road, Santa M aria, CA 93455.

${ }^{2} \mathrm{~F}$ arm advisor, U niversity of California Cooperative Extension, 420 South Wilson Way, Stockton, CA 95205.

${ }^{3}$ Farm advisor, U niversity of California Cooperative Extension, 1432 Abbott Street, Salinas, CA 93901.

${ }^{4}$ Extension weed ecologist, D epartment of Vegetable Crops, U niversity of California, D avis, CA 95616

${ }^{5}$ Extension vegetable specialist, D epartment of Vegetable Crops, U niversity of California, Kearney Agricultural C enter, 9240 South Riverbend Avenue, Parlier, CA 93648.

${ }^{6}$ Farm advisor, U niversity of California Cooperative Extension, 1432 Abbott Street, Salinas, CA 93901. 


\section{Registration and certification process}

Registration permitsthe legal sale of produce or a product as organic in California. The regulating agency is the California Department of Food and Agriculture (CDFA), usually acting through the local county agricultural commissioner. The CD FA maintains a list of materials that can be used in an organic operation (CDFA, 1999) and there are strict limits on the farm inputs that are allowed. Registration requires an annual affirmation by the grower of compliancewith CDFA standards. Restrictions change from year to year and additional information is available through county agricultural commissioner's offices or through the CDFA (CDFA, 1999).

Certification isaprocesswhereby an organic production, handling, processing, or retailing enterprise is certified as following organic production and handling practices. The certification process is regulated by private, independent certifying agencies that in turn are regulated by the CDFA. Certification allows a product to be marketed as certified organic. It is a much morecompleteand comprehensive process than registration and usually requires an annual farm inspection, maintenance of an audit registry of specific crop management, handling, and input use, and an affidavit of compliance. The certifying agency may also require a comprehensive long-term program for soil and pest management.

In California, registration and certification currently permit use of the terms organic and certified organic only after a period of at least 3 years during which no prohibited product has been used. CDFA permits a product to be marketed as transitional organic if the grower follows organic production practices but has not yet completed the minimum time requirement to be registered organic. Some certifying agencieswill al so certify transitional product.

As the organic market evolves, processors and handlers are also becoming certified and each processor or marketer may have specific certification requirements. Growers should identify their most promising markets and make sure that their certification will meet the requirements of those markets. If the product is for export, the grower uses the requirements of the countries where the product will besold. Certifying agenciessuch asthe O rganic Crop I mprovement Association are less active in California but more active internationally and may have standards that more closely correspond to the standards of some foreign markets. There is a trend overall for $C$ alifornia-based certifiers to communicate and cooperate with international agenciesto maintain broad marketing options for $\mathrm{C}$ alifornia growers.

\section{Farm management}

D ifferent aspects of farm management are complicated by the special requirements for organic vegetable production management. Several of these considerations are summarized in Table 1.

O rganic vegetable farmers view soil quality or health as afoundation to successful production. O utlined here are specific factorsthat addressorganic soil management.

\section{Organic soil management}

SoIl QUALITY ASSESSMENT. D uring the last decade, there has been considerable discussion related to assessment of soil health and the related impact of soil management practices ( $K$ arlen et al., 1997; Sojkaand U pchurch, 1999). Good soil quality in one context may not be directly comparable to another and quantitative assessment is often difficult. There is, however, a growing awareness and recognition that much like air or water quality, the quality of soil has a profound impact on the health and productivity of a given agroecosystem and on the ecosystems that interface with it ( $\mathrm{N}$ ational $\mathrm{Re}$ search Council, 1993). U nlike air or water quality, for which rather rigidly defined quality standards have been established, the definition and assessment of soil quality is more problematic (Sojka and U pchurch, 1999). Parameters that are frequently identified as soil quality indicators are listed in Table 2.

ROLE OF ORGANIC MATTER AND HUmus. Soil organic matter (SO M) content is frequently identified as a primary component of soil quality assessment and increasing soil organic matter is a goal of most organic production operations. SO M influencesmany soil properties including infiltration rate, bulk density, aggregate stability, cation exchange capacity and biological activity, all of which are related to a number of key soil functions (Sikora and Stott, 1996). SO M servesasaslow release reservoir for plant macronutrients, especially nitrogen $(\mathrm{N})$, and also aids in plant micronutrient nutrition. I t facilitates infiltration of water and air into the soil, increases water retention by the soil and is important in maintaining soil tilth. O ver time, increases in SO M can lead to a larger and more diverse population of soil organisms and may thus enhance the biological control of pests and plant diseases. $L$ arge quantities of fresh organic mat-

Table 1. Special farm management considerations unique to organic vegetable operations.

Farm management

- Planning, record keeping for certification/ registration compliance

- Field use, planting, or harvest timing restrictions due to certification

Crop or product mix

- Marketing limitations restrict product mix

- Certification restrictions on field management

- Limitations in organic seed or transplant availability

M aterial use/ cost

- Bulk materials require special handling, storage

- Limitations on availability, cost, or uniformity of fertilizer or soil amendments

- Field/ land use due to rotation, soil building, or cover crop management

Postharvest handling

- Chlorine use resticted to 4-10 ppm $\left(\mathrm{mg} \cdot \mathrm{L}^{-1}\right)$ in dump tanks

- O ther aspects of handling optimized to compensate for restrictions on disinfection

- N ew marketers and handlers lack handling knowledge or experience

- Added prewashing useful but costly

M arketing

- Little market info available due to developing markets

- N ew markets and marketers-restrict marketing experience 
ter added to the soil, however, may stimulate plant pathogenic organisms and seed and seedling pests such as cabbage maggots (D elia radicum L.) and wireworms (Limoniussp.), which can result in serious losses. 0 ther potentially negative implications of efforts to increase SOM as a means of improving soil quality such asincreased bypass flow and transport and greater phosphorus solubility have recently been chronicled by Sojka and U pchurch (1999).

Soil organic matter contains a number of fractions of varying composition and activity. $\mathrm{H}$ umus is the most resistant and mature fraction of soil organic matter. It is very slow to decompose and may last for hundreds of years. Residues that are slow to decompose such ashay or corn (Zea mays L.) stalks are more efficient at producing humus than more readily decomposable materials such as green manure residues (Fox et al., 1990; Scow, 1997). Although relatively little is understood about the benefits of humus or other organic matter fractions on crop growth, organic crop management is often directed toward increasing total soil organic matter. $\mathrm{N}$ ative organic matter levels are relatively low in California soils, generally ranging from less than $1 \%$ to a little more than $2 \%$, and organic matter levelsfall when the soil is brought under cultivation. Studies haveshown that it isunreasonable to expect to increase appreciably overall soil organic matter (Scow, 1997) but a relatively small increase may markedly change the soil quality parametersin a given field (C olla et al., 2000).

A number of prior studies of soil organic matter related to addition of organic soil amendments and green manure have been in vitro type studies but Duxbury et al. (1989) conclude that additional applied field studies are necessary because in vitro studies " have little relevance to the behavior of soil organic matter as a source or sink of nutrients in soils". And the organic production environment may potentially alter the dynamics of soil microbial communities to such an extent that to have relevance to organic agriculture, the studies should be done in an organic production environment.

In organic production systems, soil fertility is augmented through applications of material ssuch as compost and manure and by the use of cover crops. O rganically managed soils that routinely receive these deliberate inputstypically differ in other soil quality indicator properties besides fertility when compared to conventionally managed soils (Sivapalan et al., 1993). Two major projects that are currently underway in California's Central $\mathrm{V}$ alley, the Sustainable Agriculture Farming Systems (SAFS) Project in Davis, $C$ alif., and the Biologically I ntegrated Farming Systems (BIFS) Project in Five Points, Calif., have compared soil quality indicator properties under different management systems including organic, and have found that organic soil management can result in fundamental differences in a number of soil health indicator properties including water infiltration rate (Colla et al., 2000), microbial biomass carbon, N (Gunapala and Scow, 1998), and disease suppression (van Bruggen, 1995) in the case of the SAFS comparison, and microbial biomass carbon and $\mathrm{N}$ and SOM in a number of BIFS comparisons (J .P. M itchell, personal communication). The practical significance of these management-induced differences is the focus of intense ongoing research. Preliminaryanalysesfrom the SAFS comparison project, however, suggest that while organic systems might be leakier in terms of $\mathrm{N}$ losses during thetransition period when relatively high $\mathrm{N}$ loading is often done, these systems may eventually cycle $\mathrm{N}$ more efficiently and thereby result in greater nutrient conservation (Scow et al., 1994).

Management of soll quality. A wide variety of practices are typically employed to maintain or improve soil health in organic vegetable production systems in C alifornia. These practices are generally part of long-term, site-specific management programs that aim at developing fertile and biologically active soils that readily capture and store water nutrients, have good tilth and suppress plant disease. D eliberate and routine carbon inputs are essential in organic production environmentsto achievethisgoal. Special care is needed in the selection of organic carbon so urces to assure shortterm productivity whilebuilding longterm soil quality.

Organic soll amendments. While composts and manures are frequently considered to be mainstays of fertility management programs in organic systems, these amendments often vary widely in nutritive value and are increasingly being applied as a basic carbon source to enhance overall and long-term soil health. The carbon content of these materials is also typically quite variable, though generally ranges from $20 \%$ to $40 \%$ on adry weight basis. Annual applications of composts and manures at rates of 3 to 10 tons/ acre (6.72 to 22.4 t.ha ${ }^{-1}$ ) as are commonly made in organic vegetable systems in Californiathusadd significant amounts of carbon to the soil. Though very few studies have been conducted to monitor changes in key soil quality indicator properties or processes that may result from applications of theseamendments under the broad diversity of organic vegetable systems in California, the use of organic amendments is generally associated with improved tilth, lower bulk density and increased water infiltration.

Cover CROPS. Cover cropping or green manuring is widely seen as an important part of soil quality and fertility management in organic produc-

T able 2. Indicators of soil quality.

\begin{tabular}{lll}
\hline Physical properties & C hemical properties & B iological properties \\
\hline Bulk density & pH & M icrobial biomass carbon \\
Rooting depth & Electrical conductivity & M icrobial biomass nitrogen \\
Water infiltration rate & Cation exchange capacity & Earthworms \\
Water holding capacity & Organic matter & Enzymes \\
Aggregate stability & M ineralizable nitrogen & Disease suppressiveness \\
& Exchangeable potassium & \\
& Exchangeable calcium &
\end{tabular}


tion systemsin C alifornia. Cover crops can provide a practical and economical means for supplying organic matter, enhance soil fertility, suppress weed growth, attract beneficial insects, spidersand mites, and reducenitrateleaching loss to the groundwater during periods between crops (J ackson et al., 1993a; M iller et al., 1989; Shennan, 1992). There may be reluctance to use cover crops in many farm operations because of limitations on planting and harvesting of summer cash crops and, in milder growing areas, organic vegetable growers may target early and late market windows. D epending on the specific cropping situation, the use of cover cropsalso can have potentially adverse consequences such as soil moisture depletion, temporary immobilization of plant nutrients, increased pest problems, increased management and associated costs. Recent research in the Sacramento $V$ alley suggests that cover crop-based production systems may favorably influence annual water balances (Colla et al., 2000). G rowing concern for elevated atmospheric $\mathrm{CO}_{2}$ levels and global warming may result in even greater interest in cover crops as an important means to store carbon and to improve agricultural resource use efficiency. The key to the effective and profitable use of cover crops lies in the creative design of management options to take advantage of opportunities in which they can be grown to maximum advantage within vegetable crop rotationswithout excessivefinancial loss due to land not used for cash crops. Even with the obvious benefits of agreen manure cover crop, there are limitations to green manure use.

Considerable information currently exists within California's main vegetable production regions on how to select, grow and incorporate cover crops (M iller et al., 1989). This information is readily available through county cooperative extension advisors and can be used to establish smallscale, on-farm evaluations of cover crops for specific management goals. While much of this information has been developed for winter cover crop species, several recent studies have evaluated late-summer or other nonconventional cover crop windows (S.R. Temple, personal communication). For example, while an 0 ctoberplanted, $M$ arch-incorporated rye (Secalecer ealeL.) or vetch (Vicia spp.) cover crop typically produces dry mat- ter at 10,090, or $5,600 \mathrm{lb} /$ acre $(9,000$ or $\left.5,000 \mathrm{~kg} \cdot \mathrm{ha}^{-1}\right)$, respectively in the Central Valley, an August-planted and November-incorporated sudangrass (Sorghum sudanense(Piper) Stapf) crop may provide twice as much biomass (M itchell et al., 1999).

Cover crop species mixtures are gaining wider adoption throughout California because they may provide multiple benefits to a production system and may serve as insurance for conditions which are unfavorable to a single species. Recent research conducted in the Sustainable Agriculture Farming Systems Project in D avis suggests that legume cover crops may be particularly important factors in the development of key humic acid fractions that typically distinguish organic soilsfrom conventionally managed soils and which may besignificant indices of soil quality improvement (W.R. $\mathrm{H}$ orwath, personal communication).

\section{Conservation tillage}

Studies involving a variety of tillage methods indicate major gaseous losses of carbon immediately following tillage, but point to the potential for reduced soil carbon loss and enhanced soil $\mathrm{C}$ management through the use of conservation tillage (CT) crop production practices (R eicosky and Lindstrom, 1993). Though these practices have been developed prima-

Table 3. Characteristics of organic soil amendments and fertilizer materials that limit efficient use.

N utrient availability ${ }^{2}$

- Rarely known

- Varies with material type, conditions

- Varies with environmental conditions

Physical or chemical composition

- M ay not be reported

- Inconsistent, changes during storage

- Variable, nonregulated

- M oisture content significant, variable, or unknown

Bulk

- $\mathrm{H}$ andling difficult, costly

- Special storage needs

- Affects uniformity of material and application

U niformity

- Variable among materials

- Variable within a material lot

- Changes during handling, and storage

Information

- Little available

- Variable or contradictory

- Sources variable, or inconsistent

${ }^{2}$ For nutrition of current crop. rily for erosion control in other parts of the U S, recent concerns regarding the need to sustain soil quality in areas such as California where CT is virtually nonexistent (C onservation Tillage Information Center, 1999), as well as potential global climate change have reemphasized the importance of $C T$ and how it might be implemented on a broader scale to help reduce soil $\mathrm{C}$ losses, improve soil quality, and sustain agricultural productivity.

Although CT systems are not in widespread use currently on organic vegetable farms in California, studies are underway in California on reduced tillage crop production systems and on the feasibility of using them in organic contexts. The basic feature of these systems is the use of surface organic mulches that are derived from cover crops grown off-season. Winter annual cover crops such as rye and vetch have been used successfully as both a cover crop and as a mulch in a variety of CT systems. As cover crops, these species recycle nutrients, reduce soil erosion, add organic matter to the soil and, in the case of vetch, fix N. When mowed and converted to mulch, they reduce weed emergence, lower soil temperatures during the hot summer months, reduce water loss from the soil and act as a slow-release fertilizer (Abdul-Baki and Teasdale, 1993; 1997). 
A major limitation to $\mathrm{CT}$ or cover crop mulch systems in organic crop production is the management of the cover crop so that it does not compete with or reduce the growth of the crop that is planted into it (H errero, 1999). A wide variety of management options are currently being evaluated to accomplish this (Creamer et al., 1995). Timing cover crop maturity so it is completing its life cycle at the time it is mowed, rolled or planted into, may be a useful strategy in certain contexts. H owever, this approach generally assumes that planting or transplanting the vegetable crop into the cover crop mulch will not bedoneuntil latespring. $U$ sing irrigation cutoff and relying on increasing temperatures may also kill certain cover crop species so that they do not effectively compete with the vegetable crop. Given the immense array of cover crop species available for use as surface mulches, it is likely that rapid progress can be made in further refining the economic and ecological benefits of CT production systems for organic vegetable producers.

Rotations. Judicious crop rotation may beuseful for increasing shortterm SO M and for achieving healthy, fertile and productive soils. Amounts of post harvest crop residues in organic vegetable production systems in California vary widely depending on the crop and the intensity with which it is harvested. Rotationsthat includesmall grain crops such as wheat (Triticum aestivum L.), barley ( $\mathrm{H}$ ordeum vulgare L.), oats (A vena sativa L.), rye, or triticale (Triticum $\times$ secale), that are harvested for seed, typically add 8,970 to $11,210 \mathrm{lb}$ dry matter/ acre $(8,000$ to $\left.10,000 \mathrm{~kg} \cdot \mathrm{ha}^{-1}\right)$ to the soil after harvest ( $M$ itchell et al., 1999). I ncluding these crops in a vegetable rotation may also lessen disease incidence and help with nematode control. Broccoli (Brassica oleracea L. var. botrytis L) residues typically provide nearly 7,000 $\mathrm{kg}$ of dry matter. Other vegetables such as tomato (Lycopersicon esculentum M ill.), lettuce (Lactuca sativa L.), onions (Allium cepa L.) and garlic (Allium sativum L.) may add on average, 2800. 1345, 785, and $560 \mathrm{lb} /$ acre $\left(2,500,1,200,700\right.$ and $500 \mathrm{~kg} \cdot \mathrm{ha}^{-}$ $\left.{ }^{1}\right)$ dry matter, respectively.

SOIL FERTILITY MANAGEMENT. Organic growers face special challenges in developing a soil fertility program. Soil fertility and weed management have been identified as the most im- portant factors limiting yields in low input and organic production systems in the Sustainable Agriculture Farming Systems Project trials in Davis (Chaney, 1996; Scow et al., 1994; Temple et al., 1994a, 1994b). O rganic growers in Californiastruggle to manage soil fertility in a cost effective manner given the lack of detailed information available on fertilization management in organic production systems.

The diverse types of soil amendmentsand organic material soften used for fertilization on organic farms in Californiapresent special problemsfor efficient use as a nutrient source for the current crop (T able 3). Some of these limitations, bulk, for example, also has benefits associated with the mass of organic material contributing to overall soil organic matter. The real challenge in organic systems is to build overall soil organic matter while providing adequatenutrition to the growing crop essentially through organic matter decomposition processes.

Determining nUtRIENT ReQUiReMENTS. Soil testing is essential to assess nutrient levels. Regular field testing is often a requirement for organic certification. Fertilizer recommendations based on soil tests are site and crop specific and are usually adapted from conventional fertilizer trials. In rare cases, this information may be complemented by specific organic field data, but few controlled field trials have been conducted to determine crop response to organic amendments in organic production environments. A soil test has limited useas an indication of $\mathrm{N}$ availability or $\mathrm{N}$ fertility requirements and vegetables are quite selective and variable with regard to timing and rate of $\mathrm{N}$ use.

Table 4. Common organic fertilizer materials and their approximate analysis (dry weight basis).

\begin{tabular}{lccc}
\hline & \multicolumn{3}{c}{ Fertilizer (\%) } \\
\cline { 2 - 4 } & Nitrogen & Phosphorus & Potassium \\
\hline Fish meal or powder & $10-11$ & 6 & 2 \\
Chicken manure & $2-3$ & 1.5 & 1.5 \\
Processed liquid fish residues & 4 & 2 & 2 \\
Feather meal & 12 & 0 & 0 \\
Seabird and bat guano & $9-12$ & $3-8$ & $1-2$ \\
Alfalfa meal & 4 & 1 & 1 \\
Cottonseed meal & 6 & 0.4 & 1.5 \\
Soybean meal & 7 & 2 & 1 \\
Bone meal & 2 & 5 & 0 \\
Kelp & $<1$ & 0 & 4 \\
\hline
\end{tabular}

phosphorus $(P)$, potassium (K), sulfur $(\mathrm{S})$, calcium ( $\mathrm{Ca})$, and magnesium $(\mathrm{Mg})$ is often directed toward raising these levels to optimum levels in the soil nutrient pool as determined by a soil test. $\mathrm{M}$ any cultivated soils in $\mathrm{C}$ alifornia have relatively high levels of $P$, $\mathrm{K}, \mathrm{S}, \mathrm{Ca}$, and $\mathrm{M} \mathrm{g}$. These nutrients will accumulatein soils and reach relatively high levels and thus are often not as critical to manage as $\mathrm{N}$. Broadcast additions of these nutrients may occasionally be made before planting to assure availability or to prevent depletion in the soil pool. And organic growers typically apply these materials as part of application of large volumes of compost and other organic amendments (C lark et al., 1998) as sources of $\mathrm{N}$. When soil tests indicate that nutrient imbalances exist (e.g., unfavorable Ca:M g ratio), application of individual nutrient sources may be necessary.

Crop quality and uniformity may be as important as yield with many vegetablecrops. With fresh vegetables, fertility management often is directed at improving size, color or uniformity. It is especially important to maintain high levels of available $\mathrm{N}$ when quality is a concern. Additional $P$ may also be needed in cold soils because root growth is slow and the young seedling cannot take up P quickly enough from alimited soil volume. Phosphorusavailability may improve with banded preplant application of organic $P$ sources even when soil $P$ test levels are high.

$\mathrm{N}$ itrogen is different from other macronutrients because it moves out of the root zone through leaching or gaseo usloss to the atmosphere. N itrogen availability was one of the most important factors determining to mato yieldsduring transition to organic pro- 
duction (Scow et al., 1994; Scow, 1995; Temple et al., 1994a) and microbial activity in the organic system may play an important role in this. Even with careful attempts at fulfilling nutritional needs organically, an organic vegetable production system may not reach $\mathrm{N}$ fertility levels acceptable for plant nutrition (Scow, 1996; Temple et al., 1994a, 1994b). A relatively small portion of the $\mathrm{N}$ from organic amendments is readily available in mineral forms. $\mathrm{H}$ owever, $\mathrm{N}$ mineralization continues in a typical row crop environment and if organic $\mathrm{N}$ levels are adequate, $\mathrm{N}$ will be available for plant uptake. Soil microbial populations compete with the growing crop for mineralized $\mathrm{N}$ and will also limit crop response to rates and timing of applied amendments.

$\mathrm{N}$ itrogen nutritional requirements for organic vegetables in California require an initial preplant supply and may require subsequent banded and incorporated applications. Short season crops such as leafy greens, beets (Beta vulgaris L.), or radishes (R aphanus sativus L.) may produce well with residual $\mathrm{N}$ from a green manure crop or from preplant incorporated applications alone. Longer season organic vegetablecropsfollowing a green manure may require one or more additions of $\mathrm{N}$ later in the season (Scow et al., 1994; Smith et al., 1992; Temple et al., 1994a, 1994b).

Studies with field corn in Iowa have shown that early season soil $\mathrm{NO}_{3}-$ $\mathrm{N}$ levels of 15 to $26 \mathrm{ppm}\left(\mathrm{mg} \mathrm{kg}^{-1}\right)$ soil are adequate for optimum yields (Binford et al., 1992; Blackmer et al., 1989; Blackmer, 1996). R elatively less is known about critical soil $\mathrm{NO}_{3}-\mathrm{N}$ levels for vegetables in $\mathrm{C}$ alifornia and values may differ because of theimportance of short-term $\mathrm{N}$ fluctuations on vegetable crop yield and quality. Vegetables may require equal or higher levels of soil $\mathrm{N} \mathrm{O}_{3}-\mathrm{N}$ over a longer part of the season because of more restricted root systems and potential effects of $\mathrm{N}$ deficiency on fresh market quality. Soil $\mathrm{NO}_{3}-\mathrm{N}$ of 25 ppm represents approximately $100 \mathrm{lb} /$ acre (112 $\left.\mathrm{kg} \cdot \mathrm{ha}^{-1}\right) \mathrm{N}$ in the top 12 in $(30 \mathrm{~cm})$ of soil and greater than $20 \mathrm{ppm}$ is adequate to delay subsequent side dressing in lettuce on the central $C$ alifornia coast (H artz, 1998).

As part of the long term sustainable farming systems project at U niversity of California, Davis, preplant incorporation of a high $\mathrm{N}$ green manure led to residual soil $\mathrm{NO}_{3}-\mathrm{N}$ peaks after 3 to 4 weeks followed by a return to relatively low levels ( $<10 \mathrm{ppm}$ ) for the remainder of the season (Scow, 1996; Shennan, 1992). During a 4year transition to organic production, the organic tomato system derived $85 \%$ of the $\mathrm{N}$ from a vetch cover crop (Chaney, 1996), but frequent $\mathrm{N}$ deficiency wasreported from organic plots dependent upon green manure alone for production (Scow et al., 1994; Scow, 1995; Temple et al., 1994a). The $\mathrm{NO}_{3}-\mathrm{N}$ availability from green manure is variable from season to season and is dependent upon many factors including the quality of green manure. Fox et al. (1990) reported that from $11 \%$ to $47 \%$ of the $\mathrm{N}$ had been mineralized after 12 weeks following green manure incorporation (depending on the species of cover crop). The relationships among microbial parameters and soil $\mathrm{N}$ in organic fiel ds are complex and subject to the variability related to the shortterm fluctuations in factors affecting them (Scow, 1995).

Nutrient sources. O rganic matter decomposition in soils can provide much of the N,P, and $S$ for crop nutrition. Phosphorus from organic amendments reacts quickly, is bound to soil minerals (Parnes, 1990), and movesverylittlefrom whereit isplaced. Potassium, $\mathrm{Ca}$, and $\mathrm{Mg}$ are relatively soluble from plant residues or soil organic matter fractions and soil minerals also contribute to the soil pool of these nutrients. O rganic matter provides a valuable balanced source of many minor elements. O ther mineral based soil amendments can be used as sources of macro or micronutrients. They rarely are needed on organic farms in California because of prior cropping history or application of relatively high rates of compost.

O rganic fertilizer materials generally are less concentrated nutrient sources than conventional fertilizers and amounts as high as 20 ton/ acre (49.4 th ha ${ }^{-1}$ ) or more, may be applied to $a$ field at one time. These fertilizer materials as a group are quite variable with respect to particle size and distribution, moisture content, nutrient content, and nutrient distribution. Some of the inconsistency is inherent in the materials because of the nature of the production and handling process and because they continue to change during transport and storage. Some growers independently attempt to determine and record the composition of specific organic fertilizer materials. Soil microbial activity is quite variable spatially and temporally due to the inherent heterogeneity of soil components (Scow, 1997). The addition of nonuniform organic materials further diminishes the predictability of factors such asnutrient availability that are dependant upon microbial processes.

Bulk dry or liquid materials and composts may be top-dressed and incorporated. Liquid materials such as processed liquid fish, liquid soybean meal, or sodium nitratemay beapplied through drip irrigation systems. Fresh manure has limited use in organic production systems because of relatively high transport costs, potential pollution problems, and possible crop injury. O rganic certifying agencies often limit type or timing of application of manure to organic production fields. Fresh manure application might be further limited by public perception of food safety issues.

Growers may need special facilities or equipment to handle these materials as moisture content adds to the bulk and cost. O rganic fertilizers frequently have a relatively small proportion of soluble nutrients and other nutrient fractions that are unavailable or only slowly available to the plant. O rganic materials may need to be applied as much as two to four weeks earlier than conventional fertilizers in anticipation of plant nutritional requirements. $\mathrm{N}$ utrient availability will depend upon microbial activity and lack of mixing and extremes of moisture or temperature will retard microbial turnover. The composition and particle size of the material can affect the rate of microbial decomposition and nutrient availability.

Green manure crops can be an economical mean to add organic matter and provide $\mathrm{N}$ for the succeeding crop. A green manure crop that includes an $\mathrm{N}$-fixing legume is the most economical means to provide $\mathrm{N}$ to a succeeding crop. Nonleguminous cover crops will not contribute $\mathrm{N}$, but may trap soluble nitrate- $\mathrm{N}$ and prevent losses dueto percolation and runoff ( Jackson et al., 1993b; Wyland et al., 1994). These cover cropsand green manure crops may also harvest $\mathrm{P}$ or $\mathrm{K}$ from deeper in the soil profile making 
them more available to the succeeding crop.

Typically, a 120 to 160 d leguminous green manure crop contributes between 150 and $250 \mathrm{lb} /$ acre (168 and $289 \mathrm{~kg} \cdot \mathrm{ha}^{-1}$ ) of N (M iller et al., 1989). Several studies show serious limitationsto green manure asthesole source of $\mathrm{N}$ for vegetable production. Plow down of high $\mathrm{N}$ green manures may lead to high peaks of excess available $\mathrm{NO}_{3}-\mathrm{N}$ followed by subsequent decline (C ampbell et al., 1994; D oran and Smith, 1991; Sarrantonio and Scott, 1988; Scow, 1996) and the synchrony of $\mathrm{N}$ availability and plant need is very critical for normal production (D oran et al., 1996, Robertson, 1997; Wagger,1989). Studies show that managing $\mathrm{N}$ from green manureis considerably more complex than from $\mathrm{N}$ fertilizers (Shennan, 1992) and $\mathrm{N}$ from a vetch green manure crop was not adequate for subsequent organic corn or tomato cropseven when supplemented with preplant poultry manure (Cavero et al., 1997, 1998; Scow, 1996, Temple et al., 1994b).

When green manure is not practical for a production system, composts and other approved organic amendments are useful. Composts are also a valuable source of $\mathrm{N}$ for sidedress application to long season vegetablesfollowing incorporation of a preplant green manure. Compost also provides $\mathrm{P}, \mathrm{K}, \mathrm{S}$, $\mathrm{Ca}, \mathrm{Mg}$, and other minor elements in low but reasonably balanced amounts. Composts are a relatively economical organic source of nutrients, but they are quite variable depending upon source, feed materials, and process. Even with good quality compost, the $\mathrm{N}$ available to the succeeding crop varies from a net loss(D ouglasand M agdoff, 1991), to variable rates from $4 \%$ to $35 \%$ (Castellanos and Pratt, 1981), to as much as $57 \%$ of applied N (Buchanan and Gliessman, 1991).

Much more research is required for composts to be used effectively as a reliable $\mathrm{N}$ fertilizer for vegetables (H artz et al., 1996; $\mathrm{H}$ artz and Giannini, 1998; H ueand Liu, 1995; Roe, 1998). A recent review of compost research concludesthat littleinformation isavailable to guide vegetable growers on the most efficient rates and timing for compost application (Roe, 1998).

The challenge with compost is to know and understand the composition and to determine how to use it most efficiently. Poor qualityor imma- ture compost may actually decrease the availability of $\mathrm{N}$ to the growing crop. The carbon to nitrogen ratio $(C: N)$ of a compost is one indication of the maturity and nitrogen availability. As the $C: N$ increases above 20:1, there is increasing tendency to tie up nitrogen from the soil. A compost with a $C: N$ of less than 20 will generally release $\mathrm{N}$ to the succeeding crop. $O$ ther quality considerations are age, particle size, $\mathrm{pH}$, salt concentration, and purity (the volume of soil, sand, etc. mixed with the compost). Compost analysis is based on dry weight, thus moisture content will add to the weight and lower the nutrient analysis. It is not unusual for commercial composts in California to have moisture contents of $25 \%$ to $30 \%$

$M$ any compost studies have involved municipal solid waste (M SW) compost or compost in addition to mineral fertilizers. Research reports of vegetable crop responses to compost alone are quite variable (Roe, 1998) perhaps due to variability of compost materials and $\mathrm{N}$ rates. Research conducted with bell peppers (Capsicum annuum L.) found that feather meal performed the best of seven different organic fertilizers (compost, pelleted chicken manure, fish meal, liquid fish, liquid soybean meal, feather meal and seabird guano), but compost was the most cost effective (Gaskell, 1999). The pattern of weekly residual soil $\mathrm{NO}_{3}-\mathrm{N}$ following compost application reaches a peak after 3 to 4 weeks and then falls to background soil levels. Repeated application of organic $\mathrm{N}$ sources may be one way of improving $\mathrm{N}$ availability and augment $\mathrm{N}$ from green manureor preplant applied compost.

A number of approved organic fertilizers are available commercially ( $T$ able 3). $\mathrm{M}$ any of these materials are by-products of processing industries.

Commercial formulations and nutrient analyses of these materials are quite variable. In general, they range from $1 \%$ to $12 \%$ nitrogen and provide $\mathrm{P}$ and/ or $\mathrm{K}$ along with $\mathrm{N}$. The shortterm availability of nutrients can be quite variable among these materials and depends largely on the nature of the material and how it was processed. In general, most of these fertilizers should be applied and incorporated uniformly before planting. They also may need to be applied in one or more supplemental top-dress applications, depending upon the growing cycle of the crop. D iluteliquid teas from these materials are sometimes applied to the soil or sprayed directly on the plant in an effort to improve nutrient availability, but research reports on the efficacy or cost-effectiveness of these teas are rare.

O ther simple fertilizer materials, which primarily offer only one macronutrient, include mined sodium nitrate $(\mathrm{N})$, blood meal $(\mathrm{N})$, rock and colloidal phosphate $(P)$, mined potassium sulfate $(K)$, green sand $(K)$

Certain by-products of the meat processing industry such as blood and bone meal have recently come under scrutiny because of food safety concerns and the potential for diseasetransmission. M ined Chilean sodium nitrate, a so urce of $\mathrm{N}$, has been an important component of organic fertilizer programs because of its low cost, solubility, and ease of use. $\mathrm{H}$ owever, many certifiers plan to restrict future use of sodium nitrate because of the longterm adverse effect of sodium on soils.

$M$ any studies confirm that composts and other organic fertilizers can be valuable sources of nutrients for intensive vegetable production but the variability of the results limits the use of compost in organic production (H artz et al., 1996; R oe, 1998). O nly limited data is reported on crop response to organic fertilizers. Repeated application of compost or other organic amendments may be one way of improving $\mathrm{N}$ availability. Reported studies thus far have not attempted to quantify the specific relative $\mathrm{N}$ contributions of a green manure, compost, or other organic fertilizers and $\mathrm{N}$ sufficiency for long season vegetable production. Much remains to be determined regarding the efficient use of commercially available composts and other organic fertilizers with or without a prior green manure incorporation.

Organic fertilizer sources commonly contain one or more minor elements. Additional conventional minor element fertilizers may be permitted by a certifying agency in specific circumstances for correction of minor element deficiencies. Application of approved source materials will raise soil levels to a range where they are not deficient. A number of liquid materials and teas are also available which provide one or more minor elements. Some of these may be used 
in irrigation systems or applied to foliage (Schwankl and M cG ourty, 1992). Field trials evaluating the effectiveness of applying minor element fertilizers when soil levels are adequate do not show consistent response by the crop. Costs of these materials are extremely variableand the value of the material in a specific situation will often depend upon cost. Some synthetic minor element fertilizers may contain hazardous materials asfillers or contaminants and there is debate over use of these materials even in small amounts in organic production systems.

Specific approved nutrient sources of $\mathrm{K}, \mathrm{C} a$, and $\mathrm{Mg}$ may be useful when indicated by a soil test. $M$ aterials such as gypsum, lime, or potassium magnesium sulfate have been in use in agriculture for many years and their value is thoroughly tested. These materials may be used to correct deficiencies or imbalances of potassium, calcium, or magnesium or also, in the case of lime, to raise soil pH . Gypsum is also applied to replace exchangeable sodium before leaching a high sodium soil or to improve water infiltration on clay soils with poor structure.

$M$ aterials derived from kelp and other processed seaweed contain nutrientsand, often, plant hormonesand growth regulators. Microbial soil stimulants are claimed to enhance growth and, in some cases, to reduce soil pests. Brix mixes, humates, foliar nutrient and sugar solutions, and other materials are applied to raise nutrient or sugar levels (Brix) in plant sap in an attempt to improve plant resistance to pests. Little replicable scientific information exists which clearly establishes the efficacy or cost / benefit of these materials in crop production.

$M$ aterials lists have been developed by the CDFA O rganic Program (CD FA, 1999) and independent certifying agencies and offer a broad range of materials to supplement crop nutritional needs. $M$ aterials from organic or natural sources may have dangerous levels of contaminants such as salts, heavy metals, boron, etc., which could accumulate to toxic levels on a given field.

The transitional period for new organic operations is frequently the most demanding for soil fertility management. This is because the benefits of soil building and soil organic matter improvement have not yet been realized but the grower has few soluble fertilizer materials available. Growers gain experience during thetransitional period and, as the soil organic matter builds; the benefits are often reflected in improved soil management.

\section{Weed management}

$M$ anaging weeds in organic vegetable systemsrequirestheuse of many techniques and strategies in order to achieve economically acceptable weed control and yields. Cultural practices used to produce vegetables often provide an opportunity for the crop to gain an advantage over the weeds: e.g. use of transplants, preemergent flaming of weeds, pregerminating weeds, plastic mulches and close cultivation. The goal is for the crop to outcompete and reduce the availability of reso urces for weeds. I f the use of various organically acceptable techniques can give the crop a competitive advantage, subsequent hand weeding operations and costscan beminimized. Thefollowing are many of the common techniques that are available to organic growersto manage weeds in vegetable production operations.

Water management. There are a number of ways that careful irrigation management can assist growers in reducing weed pressure on their crops.

1) The M editerranean climate of California with dry summer weather allows growers to use a dust mulch to avoid weeds (Bell, 1989). Weeds are germinated by an irrigation, killed by cultivation and the top few inches of soil are allowed to dry and form a dust mulch. Large seeded vegetables such as corn (Zea mays L.), squash (Cucurbita pepo L.) or beans (Phaseolus vulgaris L.), are planted through the dry soil into the zone of soil moisture. The seed of these crops can germinate, grow and provide partial shading of the soil surface without supplemental irrigations that would otherwise providefor an early flush of weeds.

2) Drip irrigation is widely used on many types of vegetables in C alifornia. D rip irrigation tape buried 6 to 8 inches $(15$ to $20 \mathrm{~cm}$ ) below the surface of the bed can provide moisture to the crop and minimize the amount of moisture that is available to weeds on the surface (Grattan et al., 1988). If properly managed, this technique can provide significant weed control during the nonrainy periods of the year.

3) Pregermination of weeds just before planting a cash crop is widely used in organic vegetable production. The germinated weeds are killed by shallow cultivation or flaming before planting the cash crop and can reduce initial weed pressure (Schlesselman, 1989).

Crop competition. Crops that grow vigorously can often out compete weeds (Lanini and LeStrange, 1991). Increasing the density of the crop by decreasing the in-row spacing or using closer row spacing improves crop competition ( $\mathrm{McW}$ horter and Sciumbato, 1988; and N orris, 1992). Thisallowsthecrop to close thecanopy more rapidly and reduces the ability of weeds to compete. Some crops compete effectively with weeds if given an early competitive advantage (e.g. tomato, broccoli (Brassica oleracea L.), beans and sweet corn), while others never establish a competitive canopy (e.g., onion (Allium cepa var. cepa L.) and garlic. The use of transplants give the crop an advantage over the weeds because they are larger and more developed at planting. With help from subsequent cultivation and/ or hand weeding operations, the crop can develop a full canopy more rapidly and crowd out weeds.

Reducing the weed seed bank. Practices that reduce weed seed production reduce weed pressure and can help reduced weeding costs over time. The longevity of weed seed in the soil necessitates the practices that minimize or eliminate additions to the seedbank (N orris, 1981). Short season crops such as lettuce (Lactuca sativa L.) can provide opportunities for frequent cultivationsand rapid turnover of crops, thusreducing the ability of some weeds to mature and set seed. The use of highly competitive cover crops such as cereal rye (Secale cer eale L.) and oats (A vena sativa L.) can fill in niches, out compete and smother weeds (Aldrich and Kremer, 1997; Bugg et al., 1996). Carrying weed plants with matureseed out of thefield during hand weeding operations for subsequent disposal can also significantly reduce weed seed in the field (Schlesselman et al., 1989).

Cultivation. Cultivation isatimetested technique to control weeds in vegetable production. M any approaches and philosophies regarding cultivation exist (Bowman, 1997). California vegetable operations employ close cultivation on crops such as lettuce and broccoli in which up to 80 
to $85 \%$ of the bed is cultivated early in the cropping cycle. Cultivators set up on sleds allow for careful guidance of the implement and speeds of up to 5 miles ( $8 \mathrm{~km}$ ) per hour.

A new generation of cultivators have been developed to remove weeds from between the seed rows, and in some situations, from the seed row (Wallaceand Bellinder, 1992). Springtine cultivators, torsion Bezzerides cultivators (Bezzerides Bros., O rosi, California), Budding in-row weeders, and brush hoes all have action that can be adjusted to take out weeds between and close to the seed row. Some of these cultivators can remove weeds from the seed row on cropswith tough stems (i.e. cotton). Computer guided cultivatorsthat can distinguish between the crop and weeds are being developed and may soon be available to selectively remove weeds from within the seed row (Slaughter et al., 1995).

It is easier to remove weeds by cultivation whilethey aresmall ( $L$ anini and LeStrange, 1994). Proper timing between cultivations depends on the speed of weed growth: I n spring the 2to 3-week period is about right, in the fall or winter, longer periods between cultivations may suffice. Even the best cultivatorswill not eliminateall weeds, thus hand weeding is often needed. Costs of hand weeding following cultivation varies due to weed pressure. Vegetables planted at high densities on the bed afford little opportunity for cultivation (i.e., bulb and green onions) and can have hand weeding costs as high as $\$ 600$ or more per acre (\$1482 / ha); C rops such as summer squash where cultivation can be used effectively, will have weeding costs as low as $\$ 150$ per acre ( $\$ 370 / \mathrm{ha})$ (Klonsky et al., 1994).

Flamers. Flaming is a popular method of controlling weeds in organic vegetable production operations in California. It is used on a wide variety of crops preemergence: peppers (Capsicum annuum L.), carrots (D aucus carota L.), onions, parsley (Petroselinum crispum (Mill.) A.W. Hill var. crispum), potato (Solanum tu berosum L.) and parsnips (Pastinaca sativa L.) (M elander, 1998). In addition, flaming can be used with due caution postemergence on young onion (Rifai et al., 1996) and garlic or as a directed treatment to the base of tougher cropssuch assweet corn when they aretwelveor moreinches $(30 \mathrm{~cm})$ in height (Schlesselman et al., 1989; Tim Prather, personal communication). Flaming is one of the more economical methods of controlling weeds in organic vegetable operations with the costs varying from $\$ 30$ to 35 per acre ( $\$ 74$ to $\$ 86 / \mathrm{ha}$ ) depending upon the amount of propane that is consumed in the operation (Klonsky et al., 1994).

Sterilization. Soil sterilization in organic agriculture involvesusing heat or naturally generated biocides to kill weeds. Large quantities of fuel and water are required for steam sterilization and, as a result, this technique is expensive and its use islimited to small acreages of high-value vegetable operationssuch asin greenhouse culture. $O$ zone is a naturally occurring biocide that is being experimented with as a soil sterilant (Pauwels, 1989). O zone is generated mechanically and then injected into the soil. I t shows promise for reducing weeds but it is unclear at this time if this technique will be an organically acceptable practice.

Soil solarization involves placing a clear plastic mulch over a tilled, moist soil to allow the solar energy to heat thesoil and kill germinating weed seeds (Bell, 1984; Bell et al., 1985; Stapleton and G arza-L opez, 1988; Egley, 1990; Abu-Irmaileh, 1991; and Elmore et al., 1991). It is frequently used in interior and desert valleys where summer daytime temperatures frequently exceed 80 to $90^{\circ} \mathrm{F}\left(27\right.$ to $\left.32^{\circ} \mathrm{C}\right)$. I t has been successfully used on small seeded crops that are expensive to hand weed such as carrots and onions. Along the coastal production districts, the temperatures are not reliably high enough to justify its use.

Mulches. O paque plastic mulches blocks light, preventing weed germination or growth (Bonanno, 1996). They are used on crops such as peppers, strawberries (Fragaria xananassa D uchesne) melons (Cucumismelo L.) and tomatoes (M onkset al., 1997). The most common plastic color for weed control is black, as it completely blocks light. However, brown and green mulches are used because they allow more heat to be transmitted to the soil, but still offer the benefits of weed control (Purser, 1993). Certain weedssuch asyellow nutsedge (C yperus esculentusL.) are not completely controlled by plastic mulches, as they are ableto penetratetheplastic (I gbokwe, 1996). O ther weeds are also able to grow in the openings provided for crops. Plastic mulches are expensive (i.e., $\$ 250$ to $300 / \mathrm{A}$; $\$ 618$ to $\$ 741 /$ ha) and disposal after crop harvest is a problem because they are currently not recyclable.

L ayers of organic residuemulches such as municipal yard waste, straw, hay, wood chips, etc., must be maintained in a layer four or more inches $(10 \mathrm{~cm})$ thick in order to provide control of annual weeds ( $M$ akus et al., 1994). O rganic residuemulchesbreakdown with time and the original thickness typically reduces by 60 percent after one year ( $\mathrm{H}$ andreck and Black, 1989). Coarse green waste works better asa mulch. O rganic residue mulches are rarely used in vegetable production in California because of their costs, as well as the additional hauling and spreading costs.

Cover cropscan be grown, under cut and left on the beds to form an organic mulch (Creamer et al., 1995). Plantsused to produceorganicmulches include various cereals, clovers (Trifoli um ssp.), vetches (Vicia ssp.) and fava beans (Vicia faba L.) (A bdul-Baki and Teasdale, 1993 and 1997). Organic mulches provide some weed control, as well as other benefits on the growth of vegetables. They are currently the subject of a great deal of research in the interior valleys on crops such as processing tomatoes (H errero, 1999), but at present, their use is limited.

Beneficial organisms. Weeds suffer attacks from disease and insects as do crops. H owever, at present, most instances of biological control of weeds occur in range or noncrop areas and are of little consequence to vegetable growers. There is interest in developing microbial agents that selectively attack the above ground portions of weeds and weed seeds of vegetables and field crops. Research is currently underway evaluating these approaches (Kremer, 1993; and Steve Fennimore, personal communication).

Chemical controls. Herbicides arechemicalsthat kill or suppressplants by affecting plant physiological processes. The number of herbicides that are organically acceptable are limited and include contact materials such as acetic acid (vinegar) (Lanini, 1997; Spencer, 1997), citric acid, solutions of sodium nitrate, as well as a preemergent material, corn gluten (Liu et al., 1994; Bingaman and Christians, 1995). H erbicides can be used to se- 
lectively control weeds by timing of the application, placement of the material, or by differential crop and weed tolerance of thetreatment. Weeds that emerge before the crop can be killed using contact type herbicides (acetic acid, etc.). Corn gluten is a preemergence material that is applied to the soil to suppress weeds as they germinate. Currently, the use of these organically acceptable herbicides is limited because of marginal efficacy and high cost

\section{Insect pest management}

The major emphasis in organic vegetable production systems is on using cultural and biological control methods for insect pest management.

The selection of appropriate crop rotations and crop residue incorporation will help prevent build up of many pest species (O nstad et al., 1999). Growing the same crop continuously on the same field contributes to increasing numbers of insect pests. Pests may also migrate from neighboring cropsand influencemanagement decisions. In the San Joaquin Valley, for example, when plant bugs such as lygus (Lyguselisus, Van Duzee) migrate into fresh market bean fields, it is not possible to stop substantial crop loss with the use of any available products approved for organic vegetable growers. For the organic vegetable grower, often the best solution to pest problems only comes with a thorough understanding of local conditions and knowing what cultivars or crops to grow and when to plant them in order to avoid the most severe problems (D osdall et al., 1996).

It is a valuable practice to keep records of the pest problems, where and when they occur and what control strategies worked. Good record keeping will help build the foundation for next year's pest control strategy.

MONITORING FOR PESTS AND Beneficials. Proper identification of thepestsand beneficialsthat arepresent in the crop is very important. Identification of the immature life stages such as eggs, nymphs and larvae will greatly aid in preventing economic damage to crops.

$M$ any of thekey pestsin vegetable crops are described in pest management manuals and literature available from the U niversity of $\mathrm{C}$ alifornia Agriculture and $\mathrm{N}$ atural Resources $\mathrm{Com}$ munications Services ( $\mathrm{O}$ akland, Ca- lif.). An experienced pest control advisor can help alert a grower to potential problems before crop losses occur. In some situations, pheromones can be used to prevent feeding damage by mass confusion of males and preventing mating (Wang et. al., 1997). It is important to determine when biological control factors are beginning to impact the pest population. U nderstanding the life cycle and biology of both pests and beneficials will help the grower make the best use of the insect community that developswith thecrop.

To follow the activity of pests and beneficials in the crop, it is important to make regular weekly checks in the field with a hand lens and inspect the underside of foliage for the first signs of insect activity. $M$ any pest species are very small and not often noticed until considerable damage has occurred. $M$ ore frequent checks may be necessary during periods favorable for rapid increase of pests such as two-spotted spider mites (Tetranychus utricae, Koch). The use of a sweep net in cover crops, field edges and adjacent crops to check for insect activity can help determine which potential beneficials or pests may be developing that could move into crops.

Tolerance levels or action thresholds have to be considered for different pest species and different crops. If the pest feeds on the fruit or part of the vegetable that is sold, then tolerances are lower. Pestsfeeding on portions of the plant that are not sold, such as the leaves of a tomato plant, can often be tolerated at much higher levels. I nsect and disease control options, including organic options that are updated regularly, are available for pests of vegetable crops in U niversity of California, Agriculture and $\mathrm{N}$ atural Resource publications. M uch information about pest control techniques, photos of pests, models of pests and information on integrated pest management research can be obtained through the $\mathrm{U}$ niversity of $\mathrm{C}$ alifornia Statewide I $\mathrm{n}$ tegrated Pest $\mathrm{M}$ anagement Project (Strand et al., 1999).

\section{Cultural control}

The time of planting and harvesting can becoordinated to avoid certain pests that build up in crops. Crops such as sweet corn can be grown with less earworm, ( $\mathrm{H}$ eliocoverpa zea (Boddie)) damage in June and early July while corn harvested in August and September will have more damage. In crops such as squash, where aphids like green peach aphid ( $M$ yzus persicae(Sulzer) can transmit virus diseases, succession planting will allow aphids to build up and severe damage may occur in the later cultivars. Planting later crops upwind may help reduce the spread of disease. In some areas, midsummer and late season plantings must be located in isolated fields. M any pests such as plant bugs ( $M$ iridae), flea beetles (Chrysomelidae), squash bugs (A nasp tristis (D egeer)) and many caterpillar species ( Lepidoptera) can build up in early crops and cause extensive damage in later plantings unless they are controlled before they mature and reproduce.

In California, the incorporation of a grass speciesinto the crop rotation is recommended, as grasses tend to be resistant to most of the insect and disease pests of the more common cash crops (Weaver et al., 1998). Resistant cultivars and trap crops are useful tools for the organic grower and may help control build up of damaging pest species ( $\mathrm{H}$ alford et al., 1999).

Planting field borders or strips within the field with plants that are different from the main crop can provide habitat for beneficial arthropods and can slow the spread of pest species in the field. Flowering plants along bordersand edges of fieldscan provide habitat and food for beneficial insects. Research has shown that substantial numbers of beneficial insects can move from hedgerows up to 23 feet $(76 \mathrm{~m})$ into adjacent vegetable fields ( $L$ ong et al., 1998). Insect, weed and wildlife pest management in borders can be challenging. The borders need to be checked to make sure that pest species are not building up and migrating out of the borders into the cropping areas.

Certain soil and nutrient conditions can be associated with pest problems. $\mathrm{H}$ igh organic matter content can lead to an increase in problems with symphylans (Symphyla), springtails (Collembola, cutworms(Lepidoptera), and seedcorn maggots(D elia platura., (M eigen)). Soil tillage can destroy insect life stages and expose them to birds, predators and speed the breakdown of plant residues. Sandy soilswill tend to support higher nematode ( $\mathrm{N}$ ematoda) and wireworms, such as the sugarbeet wireworm (Tetanops myropaeformis (Rder)), populations. 
Organic growers farming on sandy soils will need to be more careful with crops such as tomatoes, members of the cucurbit family (C urcurbitacaea), and most root crops. Longer fallow periods will be required or more frequent grass rotations will be necessary to prevent a buildup of soil pests. Growing sensitivecrops when soil conditions are not favorable for pests will help prevent damage. Fall and winter planted vegetablesmay escape damage that would be severe if the same crops were planted in thespring and summer period.

Pest barriers can be incorporated into high value vegetable plantings. Floating row covers and plastic tunnels are effective in reducing access by many pest species (O rozco et al., 1994). Reflective mulches have been effective in preventing early aphid infestations in row crops such as tomatoes, and squash (C sizinszky et al., 1999). Sticky barriers can be useful as monitoring devices; however they have seldom been effectivein control of pest species (Kim et al., 1999). M echanical control by vacuuming and destroying lygus bugs in strawberries has proven effective if frequent passes through the fields are made during critical periods.

\section{Biological control}

$M$ any opportunities for enhancing biological control exist in organic farming systems. With most organic farmsusing few pesticides, it is possible to build up large numbers of parasites and predators, which will aid in controlling pests. The addition of biocontrol organisms may be most cost effectiveduring the transition from conventional to organic production systems (Corbett and Rosenheim, 1996). Care should be taken to determine that the introduced biological control organism is well adapted to a particular site and is the correct predator or parasite species for the pest indicated. M ultiple releases of the biological control agents may be required to adequately suppress the pest populations. There are now over 125 suppliers listed that sell biological control organisms (H unter, 1997).

When pests such as aphids build to high levels, they will often be controlled by native populations of ladybird beetles (C occinellidae), lacewings (N eur optera), syrphid flies (Syr phi dae), or wasp parasites ( $\mathrm{H}$ ymenoptera). For many growers this control may be too lateto prevent extensive damage to the crop. If the aphids are vectors of virus pathogens, it only takes a few of them to cause extensive losses. In this case, predatorsand parasitesare not likely to prevent spread of disease into or through the field.

\section{Chemical control}

Some microbial insecticides such as the various Bts, (Bacillus thuringiensissubspp.) , arereadily available. The primary use is to kill larvae of butterflies and moths (Lepi doptera). Btshave little effect on other organisms but are effective on the pest for only one or two days. $\mathrm{H}$ eat, cold, time, rain, and diseases can all affect the viability of biological control agents.

Therearea number of organically acceptablechemical insecticides, which may beuseful in specific circumstances. If a particular pest needs to be treated to prevent economic losses, a selective spray material may be used but preferably only as an isolated application. Organic growers should be aware of the legal requirements in California for pesticide use in agricultural crops. For organic growers, three of the most important factors in choosing a pesticidearelow mammalian toxicity, minimal effect on beneficial organisms and adequate coverage of the crop. Pests are often feeding on the undersides of the leaves and most organically approved pesticidesmust contact thepest in order to be effective.

$M$ any organically approved pesticides degrade rapidly in the environment. This will allow more rapid establishment of biological control but in some cases may result in repeat applications for pests. Insects can become resistant to pesticides used frequently and over time those pesticides may become less effective. Pesticide resistance is not as likely to develop to materials such as oils and soaps that will control insects by physical actions such as suffocating or dislodging the pest from the crop.

\section{Plant disease management}

C alifornia agriculture, in general, is noted for its great diversity of crops. Because of this diversity, growers are faced with various disease problems for each of the many crops they might produce. This challenge is accentuated for organic vegetable growers because they usually produce a wide array of vegetable crops and do not use synthetic fungicides and fumigants. The world market will continue to be extremely competitiveand requireC alifornia growers to supply high quality, disease-free produce having acceptable shelf life. This makes disease control a challenging task for organic vegetable growers.

For controlling diseases in an organic system, California growers generally have developed strategies having an ecological basis (Gliessman, 1995; Pankhurst and Lynch, 1995; van Bruggen, 1995). For example, asmuch as possible the organic system encourages the growth and diversity of soilinhabiting and leaf-epiphytic microorganisms that might have beneficial and pathogen-antagonistic influences. Increasing the genetic diversity of the crop rotation is another ecological management step. I ntegrating disease management decisions with insect and weed control and with general production practices is another step consistent with this approach.

\section{Resistant plants and cultivars}

O ne of the most important components in an integrated disease control program isthe selection and planting of pathogen-resistant cultivars. California organic vegetable growers rely on such cultivars because their use is nondisruptive to the environment and is compatible with other disease management practices.

$\mathrm{H}$ owever, the greatest limitation of this option is that resistance is not availablefor all crops. F or several of the most damaging plant diseases, such as late blight (Phytophthora infestans (M ont.) de Bary) of tomato and white rot (Sclerotium cepivorum Berk.) of onion and garlic growers do not yet have cultivars with acceptable resistance. There are no known resistant cultivars for most of the smaller acreage specialty vegetables, such as arugula(E ruca sativa M ill.), broccoli raab (Brassica rapa L. subsp. rapa), cilantro (C oriandrum sativum L.), fennel (Foeniculum vulgare Mill.), jicama (Pachyrhizuserosus(L.) U rb.), mizuna mustard (Brassica campestrisL. subsp. nipposinica), radicchio (Cichorium intybus L.), red mustard (Brassica juncea (L.) Czernj. \& Coss. subsp. rugosa), Swiss chard (Beta vulgarisL. subsp. cicla), tah tsai (Brassica campestris L. subsp. narinosa), toma- 
tillo (Physali si xocarpa Brot.), and many Asian vegetables and herbs. In other cases resistance is present in cultivars that lack adequate horticultural characteristics. For celery (A pium graveolens L.), there are cultivars with acceptable resistant to the Fusarium yellows pathogen (Fusarium oxysporum Schlechtend.:Fr. f. sp. api i (N elson \& Sherb) Snyder \& H ans.); however, many of these selections lack adequate color, yield, and other qualities. Finding a cultivar with multiple resistances can al so bedifficult for $C$ aliforniagrowers. A lettuce (Lactucaesativa L.) cultivar that is resistant to lettuce mosaic virus may be quite sensitive to corky root disease (caused by R hizomonas suberifaci en svan Bruggen, J ochimsen, and Brown); a lettuce selection that resists corky root may be very susceptible to downy mildew (Bremia lactucae Regel).

The breakdown of resistance due to changes in the pathogen poses a constant concern for $\mathrm{C}$ alifornia growers. For example, during the past 50 years in California, a new race of the spinach (Spinacia oleracea L.) downy mildew fungus (Peronospora farinosa (Fr.:Fr.) Fr. f. sp. spinaciae Byford) would periodically occur in the state and cause significant damage to the previously resistant cultivars. Plant breeders would counter with new cultivars having resistance genes to the new race (Koike et al., 1992). G rowers would then enjoy several years of mildew-free spinach until the development of yet another race. This backand-forth dynamic has taken place for each of the seven races that has been confirmed in California.

\section{Site selection}

Experienced organic growers know that considerabletimeand effort are required for site planning. G rowers try to monitor the distribution of persistent, soil borne plant pathogenic fungi such as Armillaria (Fr.:Fr.) Staude, Fusarium Link:Fr., Plasmodiophora Woronin, Sclerotium Tode:Fr., and Verticillium $\mathrm{N}$ ees. Because not all fields are infested with these fungi, growers attempt to plant susceptible crops in sites that do not have histories of such problems. Soilborne fungi such as Phytophthora de Bary, Pythium Pringsh., and R hizoctonia DC. are often much more wide spread in California, so site selection is usually less helpful in avoiding these organisms.

Other site-specific situations also create risks that growers try to avoid. Pastures, foothills, riverbanks, and grasslandssupport weedsand natural vegetation that are often reservoirs for virus and virus-like pathogens. For example, the aster yellows phytoplasma and its six-spotted leafhopper ( $M$ acrosteles fascifr ons(Stal.)) vector can be found in weedy grasslands in coastal California. Once this vegetation dries up in the summer, the leafhoppers migrate from the grasslands and move into nearby lettuce or celery fields, resulting in aster yellows disease in these fields (Severin and Frazier, 1945).

Pertinent environmental factors are also considered in selecting sites. Crops planted close to the Pacific O cean are more at risk from downy mildew diseases due to the persistent humidity and cool temperatures. $\mathrm{H}$ owever, moving a few miles inland from the ocean can change these conditions and reduce downy mildew pressure. Soil factorsarecritical in avoiding some root and crown diseases. Choosing a site that has well draining soils reduces therisk of damping-off and root rot for sensitive crops such as spinach. In fact, the recent, significant increase of spinach acreage has caused some organic growers to place spinach in poorly draining fields, resulting in significant root rot problems.

\section{Exclusion}

Exclusion refersto preventing any materials that are contaminated with pathogens from entering the production system. For some diseases, seedborne pathogens are a primary means of pathogen introduction ( $M$ cG ee, $1981 ; 1995)$. When possible, growers purchase seed that has been tested and certified to be infested below a certain threshold level or treated to reduce pathogen infestation levels. Someseedborne diseases of concern in C alifornia are the following: lettuce mosaic and bacterial leaf spot ( $X$ anthomonas campestrispv. vitians(Brown) D ye) of lettuce; black rot ( $X$ anthomonas campestris pv. campestris (Pammel) Dowson), black leg (Phoma lingam (Tode:Fr.) Desmaz.) and Alternaria leaf spot (A. brassicae(Berk.) Sacc.) of cabbage (Brassica oleracea L. var. capitata L.); bacterial leaf spot (Pseudomonas syringae van $\mathrm{H}$ all) of cilantro; bacterial leaf spot (X anthomonas campestris pv. carotae
(Kendrick) Dye), Alternaria leaf spot (A. dauci (Kuhn) Groves \& Skolko), and Cercospora leaf spot (Cercospora carotae (Pass.) Solheim) of carrot (D aucus carota L. subsp. sativus); Septoria late blight (S. api i cola Speg.) and bacterial leaf spot (Pseudomonas syringaepv. apii (J agger) Young, D ye $\&$ Wilkie) of celery; Septoria blight (S. petroselini (Lib.) D esmaiz.) of parsley (Petroselinum crispum ( $\mathrm{M}$ ill.) $\mathrm{N}$ ym. ex. A. W. Hill); bacterial spot ( $X$ anthomonas campestris pv. vesicatoria (D oidge) Dye) of pepper (Capsicum annuum L.) and tomato; bacterial speck (Pseudomonassyringae pv. tomato (O kabe) Young, D ye \& Wilkie), and bacterial canker (Clavibacter michiganensis subsp. michi ganensis(Smith) D avis, Gillaspie, Vidaver \& $\mathrm{H}$ arris) of tomato. If transplants are used, these likewise should be as clean as possible from pathogen contamination and from disease. California organic growers are highly dependent on good quality, disease-free transplants of broccoli, Brusselssprouts (Brassica oleracea L. var. gemmifera DC .) , cauliflower (Brassica ol eracea L. var. botrytis L.), celery, leeks (Allium porrum L.), lettuce, pepper, tomato, and other vegetables.

\section{Disease control materials}

Once vegetable crops are in the field, it will sometimes be necessary to apply, if available, protectant or eradicant spray or dust materials for disease control. U nfortunately for organic producers, the choices of effective, proven materials are limited.

Inorganic control materials, primarily copper and sulfur based fungicides, aregenerally inexpensive, widely available, and pose minimal problems to the environment. H owever, disease control efficacy varies. Copper fungicides registered in California have some activity against a wide range of fungal and bacterial pathogens but generally are not extremely effective. Sulfurs also exhibit someactivityagainstmanypathogens, but usually only provide excellent control against certain pathogens such as powdery mildew fungi. Bicarbonate based fungicides have recently become available for control of plant diseases. Bicarbonates have shown someactivity primarily against powdery mildews (Erysiphe R. H edw. ex. DC.:Fr.; Sphaer otheca L ev.). H owever, field experiments and grower experience indicate that bicarbonates al one likely 
will not provide season long protection for an organically grown crop.

Oils, plant extracts, and other natural plant productsare being investigated for use for disease control. Such products will be compatible with organic production practices, but reliable disease control has yet to bedemonstrated. There is much interest in using microorganisms or the chemical by-products of microorganisms for disease control (L eggett and G leddie, 1995; M athre et al., 1999). H owever, thehistory of successful biological control of plant diseases in California has been discouraging. There are very few effective, economically feasible, and commercially available biological control materials at this time.

Cultural Practices. Specific cultural practices can be implemented to help manage diseases.

Recent research has found that certain plants, in addition to being revenue-generating crops, also have suppressive effects on various diseases. For example, after broccoli crops are harvested and the plant residue is plowed into the soil, the decomposition of the broccoli stems and leaves releases natural chemicals that can significantly reduce the severity of $V$ erticillium wilt and the number of Verticillium dahliae Kleb. microsclerotia (Subbarao et al., 1999). Broccoli as a rotation crop and even as a cover crop is now being used by California organic growers to harness this suppressive effect.

When devising crop rotation strategies, growers consider which crops and cover crops might increase disease problems (K oike et al., 1996). Purple vetch (Vicia benghalensis L.) cover crops, if planted in fields having a history of lettuce drop caused by the fungus Scler otinia minor Jagger, can greatly increase the number of infective sclerotia of this pathogen (Dillard and G rogan, 1985). G rowersal so realize the risks involved with planting the same crop back-to-back or in consecutive seasons and try to avoid such rotations.

Time of planting can offer an opportunity for disease management. If cauliflower is planted in Verticillium-infested fields in the spring or summer, it is likely the crop will experience significant disease, but cauliflower planted in the same fields in the late fall or winter will exhibit no verticillium wilt symptoms. This is attrib- uted to soil temperatures that are too cool for the fungus to develop. Proper soil preparation before planting can influence seed decay and seedling damping-off diseases by tilling to reduce plant residues left from previous crops and by making raised beds with good soil tilth and drainage.

For most foliar diseases, overhead sprinkler irrigation enhances pathogen survival and dispersal, and disease development. Bacterial diseasesare particularly dependent upon rain and sprinkler irrigation. Therefore, organic growers try to limit or eliminate sprinkler irrigation if possible. In particular, the use of surface or buried drip tape for vegetable production has increased greatly in California in recent yearsand helps reduce the severity of certain diseases.

Sanitation is useful in disease control for certain crops. O ncelettuce has been harvested, the remaining plants can act as a reservo ir for lettuce mosaic virus. Plowing the field immediately after harvest is a sanitation procedure that eliminates this potential virus so urce. L ettuce drop occurswhen sclerotia develop on lettuce plant residues and remain in the top few inches of soil. A sanitation step involves deep plowing in which mold board plows invert the soil and bury sclerotia. $N$ ote that this procedure is effective only if sclerotia are low to moderate in number (Subbarao et al., 1996).

Like other states, the use of composts in California organic systems is a fundamental cultural practice and growers are committed to compost programs. Composts are beneficial for a number of fertility and soil conditioning reasons and are considered by growers to be beneficial in disease management. Though research studiesand empirical datathat clearly document the disease control benefits of field-applied compost are lacking, organic growers in California will continue to use composts and to experiment with variations such as compost teas.

\section{Literature cited}

Abdul-Baki, A.A. and J.R. Teasdale. 1993. A notillage tomato production system using hairy vetch and subterranean clover mulches. $\mathrm{H}$ ortScience 28:106-108.

Abdul-Baki, A. and J. Teasdale. 1997. Sustainable production of fresh-market tomatoes and other summer vegetables with organic mulches. USDA-ARS, Beltsville (Md.) Agr. Res. Ctr.-
West Farmers Bul. 2279.

Abu-I rmaileh, B.E. 1991. Weed control in squash and tomato fields by soil solarization in the Jordan valley. Weed Res. 31:125-133.

Aldrich, R.J . and R.J. Kremer. 1997. Principlesin weed management. $2^{\text {nd }}$ ed. I owa State U niv. Press, Ames, I owa.

Bell, C.E. 1984. Innovative weed management practicesin the southern $C$ alifornia desert region. Proc. Calif. Weed Conf. 36:121-122.

Bell, C.E. 1989. M uskmelons (Cucumis melo) and watermelons (Citrullusmelo)., p. 341-344. In:E.A. Kurtz and F.O . Colbert (eds.). Principles of weed control in California. Thomson Publications, Fresno, Calif.

Bell, C.E., A. Durazo, III, and C.L. Elmore. 1985. Weed management in specialty farms. Calif. Agr. 39:17-18.

Binford, G.D ., M .E. Cerrato, and A.M . Blackmer. 1992. Relationships between corn yields and soil nitrate in late spring. Agron. J. 84:53-59.

Bingaman, B.R. and N.E. Christians. 1995. Greenhouse screening of corn gluten meal as a natural control product for broadleaf and grass weeds. H ortScience. 30:1256-1259.

Blackmer, A.M ., D. Pottker, M.E. Cerrato, and J. Webb. 1989. Correlations between soil nitrate concentrations in late spring and corn yields in Iowa. J. Prod. Agr. 2:103-109.

Blackmer, A.M. 1996. Calibration of the latespring soil nitrate test for manured soils. lowa StateU niv., Ames, L eopold C enter ProgressR pt. 5:26-29.

Bonanno, A.R. 1996. Weed management in plasticulture. H ortT echnology 6:186-189.

Bowman, G. (ed.). 1997. Steel in the field: A farmer's guide to weed management tools. Sustainable Agriculture $\mathrm{N}$ etwork, Beltsville, $\mathrm{M} \mathrm{d}$.

Bugg, R.L., G. M cGourty, M . Sarrantonio, W.T $L$ anini, and R. Bartolucci. 1996. Comparison of 32 cover crops in organic vineyards on the north coast of California. Biol. Agr. H ort. 13:63-81.

Buchanan, M. and S.R. Gliessman. 1991. H ow compost fertilization affects soil nitrogen and crop yield. BioC ycle 32:72-77.

CDFA. 1999. California organic. $28 \mathrm{~J}$ an. 2000 <http:/ / www.cdfa.ca.gov/ inspection/ fve/ organic.html>).

Campbell, C.A., G.P. Lafrond, R.P. Zentner, and Y.W. Jame. 1994. N itrate leaching in a U dic $\mathrm{H}$ aploboroll as influenced by fertilization and and legumes. J. Environ. Q ual. 23:195-201.

Castelllanos, J.Z. and P.F. Pratt. 1981. M ineralization manure nitrogen-correlation with laboratory indexes. Soil Sci. Soc. Amer. J. 45:35543557.

Cavero, J., R.E. Plant, C. Shennan, and D.B. Friedman. 1997. The effect of nitrogen source and crop rotation on the growth and yield of processing tomatoes. Nutrient Cycling Agroecosystems 47:271-282. 
Cavero, J., R.E. Plant, C. Shennan, J .R. Williams, J.R. Kiniry, and V.W. Benson. 1998. Application of epic model to nitrogen cycling in irrigated processing tomatoes under different management systems. Agr. Systems (Oxford) 56:391414.

Chaney, D . 1996. A comparison of conventional, low input and organic farming systems: The transition phase and long-term viability. Sustainable Agr. 6(2):1-6.

Clark, M.S., W.R. H orwath, C. Shennan, and K.M. Scow. 1998. Changes in soil chemical properties resulting from organic and low-input farming practices. Agron. J. 90:662-671.

Colla, G., J.P. M itchell, B.A. J oyce, L.M . H uyck, W.W. Wallender, S.R. Temple, T.C. H siao, and D.D. Poudel. 2000. Soil physical properties, tomato yield and quality in alternative cropping systems. Agron. J. (in press).

Conservation Tillage I nformation C enter. 1999. $\mathrm{N}$ ational survey of conservation tillage practices. Conservation Tillage Info. Center, West L afayette, Ind.

Corbett, A., and J.A. Rosenheim. 1996. I mpact of a natural enemy over wintering refuge and its interaction with thesurrounding landscape. E col. Entomol. 21:155-164.

Creamer, N .G., B. Plassman, M .A. Bennett, R.K. Wood, B.R. Stinner, and J. Cardina. 1995. A method for mechanically killing cover crops to optimize weed suppression. Amer. J. Alternative Agr. 10:157-162.

C sizinszky, A.A., D .J . Schuster, and J .E. Polston. 1999. Effect of ultraviolet reflective mulches on tomato yieldsand on thesilverleaf whitefly. $\mathrm{H}$ ortScience 34:911-914.

Dillard, H .R. and R.G. Grogan. 1985. I nfluence of green manure crops and lettuce on sclerotial populations of Sclerotinia minor. Plant Dis. 69:579-582.

D oran, J.W. and M.S. Smith. 1991. O verview: Role of cover crops in nitrogen cycling, p. 85-90 In: W.L. H argrove (ed.). Cover crops for clean water. Soil Conserv. Soc. Amer., Ankeny, I owa.

D oran, J.W., M. Sarrantonio, and M .A. Liebig. 1996. Soil health and sustainability. Adv. Agron. 56:1-54.

Dosdall, L.M., M.J. H erbut, N.T. Cowle, and T.M. M icklich. 1996. The effect of seeding date and plant density on infestations of root maggots, D elia spp. (Diptera: A nthomyiidae), in canola. Can. J. Plant Sci. 76:169-177.

D ouglas, B.F. and F.R. M agdoff. 1991. An evaluation of nitrogen mineralization indices for organic residues. J. Environ. Q ual. 20:368-372.

D uxbury, J.M., M.S. Smith, and J.W. Doran. 1989. Soil organic matter as a source and sink of plant nutrients, p. 33-67. In: D.C. Coleman, J.M. D ads, and G. U ehara (eds.). D ynamics of soil organic matter in tropical ecosystems. $\mathrm{N}$ iftal Project, $\mathrm{U}$ niv. $\mathrm{H}$ awaii, $\mathrm{H}$ onolulu.

Egley, G.H . 1990. H igh-temperature effects on germination and survival of weed seeds in soil.
Weed Sci. 38:429-435.

Elmore, C.L. 1991. Weed control by solarization, p. 61-72. In: J. Katan and J.E. D eV ay (eds.). Soil solarization. CRC Press, Boca Raton, Fla.

Fox, R.H ., R.J.K. M yers, and I. Vallis. 1990. The nitrogen mineralization rate of legume residues in soil as influenced by their polyphenol, lignin, and nitrogen contents. Plant Soil 129:251-259.

Gaskell, M. 1999. Agronomic and economic evaluation of seven organic nitrogen fertilizers applied to bell peppers. HortScience 34:199 (abstr.).

Gliessman, S. R. 1995. Sustainable agriculture: an agroecological perspective, p. 45-57. In: J.H . Andrews and I. Tommerup (eds.). Advances in plant pathology. vol. 11. Academic Press, San Diego.

Grattan, S.R., L.J. Schwankl, and W.T. Lanini. 1988. Weed control by subsurfacedrip irrigation. Calif. Agr. 42:22-24.

Gunpala, N. and K.M . Scow. 1998. Dynamics of soil microbial biomass and activity in conventional and organic farming systems. Soil Biol. Biochem. 30:805-816.

H alford, P.D., M .D. Russell, and K. Evans. 1999 U se of Resistant and susceptible potato cultivars in the trap cropping of potato cyst nematodes, Globodera pallida and G. rostochiensis Ann. Appl. Biol. 134:321-327.

$\mathrm{H}$ andreck, $\mathrm{K}$. and N. Black. 1989. Growing mediafor ornamental plants and turf. $\mathrm{N}$ ew South Wales Press, Kensington.

$\mathrm{H}$ artz, T.K. 1998. Evaluation of pre-sidedress soil nitratetesting to determinenitrogen requirements of cool season vegetables, p. 47-48. Proc. Annu. Fert. Res and Educ. Prog. Conf., Calif. D ept. Food and Agr., Sacramento.

H artz, T.K., F.J. Costa, and W.L. Schrader. 1996. Suitability of composted green waste for horticultural uses. H ortScience 31:961-964.

H artz, T.K. and C. Giannini. 1998. D uration of composting of yard wastes affects both physical and chemical characteristics of compost and plant growth. H ortScience 33:1192-1196.

H errero, E.V. 1999. U se of cover crop mulches in a furrow irrigated processing tomato production system. M S thesis. U niv. Calif., D avis.

H ue, N.V. and J. Liu. 1995. Predicting compost stability. Compost Sci. U tilization 3(2):8-15.

H unter, C.D. Suppliers of beneficial organismsin $\mathrm{N}$ orth America. 1997. C alif. Environ. Protection Agency, D ept. PesticideR egulation, Sacramento, No. PM 97-01.

Igbokwe, P.E. 1996. Mulching for nutsedge control in field-grown peppers. J. Veg. Crop Prod. 2:47-53.

J ackson, L.E., L. Wyland, J .A. Klein, R.F. Smith, W.E. Chaney, and S.T. Koike. 1993a. Winter cover crops can decrease soil nitrate leaching potential. Calif. Agr. 47:12-15.

Jackson, L.E., L.J. Wyland, and L.J. Stivers.
1993. Winter cover crops to minimize nitrate losses in intensive lettuce production. J. Agr. Sci. (Cambridge) 121:55-62.

Karlen, D.L., M .J. M ausbach, J.W. D oran, R.G. Cline, R.F. H arris, and G.E. Schuman. 1997. Soil quality: A concept, definition, and framework for evaluation. Soil Sci. Soc. Amer. J. 61:4-10.

Kim, J.-K., J.-J. Park, C.H . Pak, H . Park, and K. Cho. 1999. Implementation of yellow sticky traps for management of greenhouse whitefly in cherry tomato greenhouse. J. Korean Soc. H ort. Sci. 40(5):549-553.

Klonsky, K., L. T ourte, D. Chaney, P. Livingston, and R. Smith. 1994. Cultural practicesand sample costs for organic vegetable production on the Central Coast of California. Giannini Foundation Info. Ser. 94-2, Div. Agr. Natural Resources, U niv. Calif.

Koike, S.T ., R.F. Smith, L.E.J ackson, L.J. Wyland, J.I. Inman, and W.E. Chaney. 1996. Phacelia, lana woollypod vetch, and Austrian winter pea: Three new cover crop hosts of Sclerotinia minor in California. Plant D is. 80:1409-1412.

Koike, S. T., R.F. Smith, and K.F. Schulbach. 1992. Resistant cultivars, fungicides combat downy mildew of spinach. Calif. Agr. 46:29-31.

Kremer, R.J. 1993. M anagement of weed seed bankswith microorganisms. E col. Appl. 3(1):4252.

Lanini, W.T. and M. LeStrange. 1991. Lowinput management of weeds in vegetables. $C$ alif. Agr. 45:11-13.

Lanini, W.T. and M. LeStrange. 1994. Weed control economics in bell pepper (Capsicum annuum) with napropamide and hand weeding. Weed Technol. 8:530-535.

L anini, W.T. 1997. N onchemical weed management in urban settings. Proc. Calif. Weed Sci. Soc. 49:17-21.

L eggett, M .E. and S.C. Gleddie. 1995. D eveloping biofertilizer and biocontrol agents that meet farmers' expectations, p. 59-74. I n: J.H . Andrews and I. Tommerup (eds.). Advances in plant pthology. vol. 11. Academic Press, N ew York.

Liu, D.L.Y., N.E. Christians, and J.T. Garbutt. 1994. Herbicidal activity of hydrolyzed corn gluten meal on three grass species under controlled environments. J. Plant Growth Regulation 13:221-226.

Long R., A. Corbett, C. Lamb, C. RebergH orton, J. Chandler, and M. Stimmann. 1998. Beneficial insects move from flowering plants to nearby crops. Calif. Agr. 52:23-26.

M akus, D.J., S.C. Tiwari, H.A. Pearson, J.D. $\mathrm{H}$ aywood, and A.E. Tiarks. 1994. O kra production with pine straw mulch. Agrofor. Systems 27:121-127.

M athre, D.E., R.J. Cook, and N.W. Callan. 1999. From discovery to use: Traversing the world of commercializing biocontrol agents for plant disease control. Plant D is. 83:972-983.

M cGee, D. C. 1981. Seed pathology: its place in modern seed production. Plant $D$ is. 65:638-642. 
M cGee, D. C. 1995. Epidemiological approach to disease management through seed technology. Annu. Rev. Phytopathol. 33:445-466.

M cWhorter, C.G. and G.L. Sciumbato. 1988. Effects of row spacing, benomyl, and duration of sicklepod (C assi a obtus folia) interference on soybean (Glycine max) yields. Weed Sci. 36:254259.

M elander, B. 1998. Interaction between soil cultivation in darkness, flaming and brush weeding when used for in-row weed control in vegetables. Biol. Agr. H ort. 16:1-14.

M iller, P.R., W.L. Graves, W.A. Williams, and B.A. M adsen. 1989. Cover crops for California agriculture. Div. Agr. N atural Resources, U niv. Calif., $\mathrm{O}$ akland, L flt. 21471.

M itchell, J.P., T. H artz, S. Pettygrove, D. M unk, D. M ay, F. M enezes, J. Diener, and T.O' $\mathrm{N}$ eill. 1999. O rganic matter recycling varies with crops grown. Calif. Agr. 53:37-40.

M onks, C.D., D.W. M onks, T. Basden, A. Selders, S. Poland, and E. Rayburn. 1997. Soil temperature, soil moisture, weed control, and tomato (Lycopersicon esculentum) response to mulching. Weed Technol. 11:561-566.

$\mathrm{N}$ ational Research Council. 1993. Soil and water quality: An agendafor agriculture. $\mathrm{N}$ ational Academy Press, Wash., D.C.

N orris, R.F. 1981. Zero tolerance for weeds? Proc. Calif. Weed Conf. 33:46-49.

N orris, R.F. 1992. Case history for weed competition/ population ecology: barnyardgrass (Echinochloa crusgalli) in sugarbeets (Beta vulgaris). Weed Technol. 6:220-227.

O nstad, D.W., M .G. J oselyn, S.A. I sard, E. L evine, J.L. Spencer, L.W. Bledsoe, C.R. Edwards, C.D. Di Fonzo, and $\mathrm{H}$. Wilson. 1999. M odeling the spread of western corn rootworm (C ol eoptera: Chrysomelidae) populationsadapting to soybeancorn rotation. Environ. Entomol. 2:188-194.

O rozco, S. M ario, O.A. Lopez, O.Z. Perez, and F.S. D elgadillo. 1994. Effect of transparent mulch, floating row covers and oil sprays on insect populations, virus diseases, and yield of cantaloupe. Biol. Agr. H ort. 10:229-234.

Pankhurst, C.E. and J.M . L ynch. 1995. Therole of soil microbiology in sustainable intensive agriculture, p. 229-247. In: J.H. Andrews and I. Tommerup (eds.). Advances in plant pathology. vol. 11. Academic Press, San D iego.

Parnes, R. 1990. Fertile Soil: A grower's guide to organic and inorganic fertilizers. Fertile Ground Books, D avis, Calif.

Pauwels, F. 1989. Soil disinfestation in Belgian horticulture: A practical view. ActaH ort. 255:3135.

Purser, J. 1993. U sing plastic mulch and row covers to produce vegetables in Alaska. Plasticulture 99:11-18.

Reicosky, D.C. and M.J. Lindstrom. 1993. Fall tillage method: Effect on short-term carbon dioxide flux from soil. Agron. J. 85:1237-1243.
Rifai, M.N., M. Lacko-Bartosova, and V. Puskarova. 1996. Weed control for organic vegetable farming. Rostlinna Vyroba 42:463-466.

Robertson, G.P. 1997. N itrogen use efficiency in row-crop agriculture. Crop nitrogen use and soil nitrogen loss, p. 347-365. In: L.E. J ackson (ed.). Ecology in agriculture. Academic Press, $\mathrm{New}$ York.

Roe, N.E. 1998. Compost utilization for vegetable and fruit crops. H ortScience 33:934-937.

Sarrantonio, M. and T.W. Scott. 1988. Tillage effects on availability of nitrogen to corn following a winter green manure crop. Soil Sci. Soc. Amer. J. 52:1661-1668.

Scow, K.M . 1995. I mpact of microbial processes on crop use of fertilizersfrom organic and mineral sources. Proc. 3rd Annu. Fert. Res. Educ. Prog. Conf., p. 23-28. Calif. D ept. Food Agr., Sacramento.

Scow, K.M . 1996. I mpact of microbial processes on crop use of fertilizersfrom organic and mineral sources. Proc.4th Annu. Fert. Res. Educ. Prog. Conf., p. 72-74. Calif. D ept. Food Agr., Sacramento.

Scow, K.M. 1997. Soil microbial communities and carbon flow in agroecosystems, p. 367-412. In: L.E. Jackson (ed.). Ecology in agriculture. Academic Press, $\mathrm{N}$ ew York.

Scow, K.M ., O, Sinasco, N . Gunapala, S. L au, R. Venette, H. Ferrris, R. M iller, and C. Shennan. 1994. T ransition from conventional to low-input agriculture changes soil fertility and biology. Calif. Agr. 48:20-26.

Schlesselman, J.T., G.L. Ritenour, and M.S. $\mathrm{H}$ ile. 1989. Cultural and physical control methods, p. 45-60. In: E.A. Kurtz and F.O. Colbert (eds.). Principles of weed control in California. Thomson Publications, Fresno, Calif.

Schwankl, L.J. and G. M cG ourty. 1992. O rganic fertilizers can be injected through low volume irrigation systems. Calif. Agr. 46:21-23.

Severin, H.H.P. and N.W. Frazier. 1945. California aster yellows on vegetable and seed crops. H ilgardia 16:573-596.

Shennan, C. 1992. Cover crops, nitrogen cycling, and soil properties in semi-irrigated vegetable production systems. H ortScience 27:749754.

Sikora, L.J. and D.E. Stott. 1996. Soil organic carbon and nitrogen, p. 157-167. I n:J.W. D oran and A.J. J ones (eds.). M ethods for assessing soil quality. Soil Sci. Soc. Amer. Spec. Publ. 49.

Sivapalan, A., W.C. Morgan, and P.R. Franz. 1993. M onitoring populations of soil microorganisms during a conversion from a conventional to an organic system of vegetablegrowing. Biolog. Agr. $=$ H ort. 10:9-27.

Slaughter, D.C., R.G. Curley, P. Chen, and D.K. Giles. 1995. Robotic cultivator. U.S. Patent $5,442,552$. U .S. Patent O ffice, Wash., D.C.

Smith, R., E. Aguilar, P. Elam, and P. Foster. 1992. M anagement of nitrogen from a cover crop and feather meal for bell pepper production. U niv. Calif. Coop. Ext., San Benito County, H ollister, Res. Rpt.

Sojka, R.E. and D.R. U pchurch. 1999. Reservations regarding the soil quality concept. Soil Sci. Soc. Amer. J. 63:1039-1054.

Stapleton, J.J. and J.G. Garza-Lopez. 1988 M ulching of soils with transparent (solarization) and black polyethylene films to increase growth of annual and perennial crops in southwestern M exico. Trop. Agr. 65:29-33.

Strand, J., B. Dryer, and K. Garvey. 1999. IPM O nline. U niversity of California statewide integrated pest management project. $10 \mathrm{~J}$ une 2000. 〈http:/ / www.ipm.ucdavis.edu>.

Subbarao, K.V., J.C. H ubbard, and S.T. Koike. 1999. Evaluation of broccoli residue incorporation into field soil for Verticillium wilt control in cauliflower. Plant D is. 83:124-129.

Subbarao, K. V., S.T. Koike, and J.C. H ubbard. 1996. Effects of deep plowing on the distribution and density of Sclerotinia minor sclerotia and lettuce drop incidence. Plant $D$ is. 80:28-33.

Temple, R.R. O.A. Somasco, M. Kirk, and D. Friedman. 1994a. Conventional, low-input and organic farming systems compared. Calif. Agr. 48:14-19.

Temple, S.R., D.B. Friedman, O . Somasco, $H$. Ferris, K. Scow, and K. Klonsky. 1994b. An interdisciplinary experiment station-based participatory comparison of alternative crop management systems for California's Sacramento Valley. Amer. J. Alternative Agr. 9:64-71.

Tourte, L and K. Klonsky. 1998. Statistical review of California's organic agriculture. Agr. I ssues Ctr., U niv. Calif., D avis, Spec. Publ.

van Bruggen, A.H .C. 1995. Plant diseaseseverity in high-input compared to reduced-input and organic farming systems. Plant D is. 79:976-984.

Wagger, M.G. 1989. Cover crop management and nitrogen rate in relation to growth and yield of no-till corn. Agron. J. 81:533-538.

Wallace, R.W. and R.R. Bellinder. 1992. Alternative tillage and herbicide options for successful weed control in vegetables. $\mathrm{H}$ ortScience 27:745749 .

Wang, K., G. Ferguson, and J.L. Shipp. 1997. Incidence of tomato pinworm, Keiferia Iycopersicella (Walsingham), (Lepidoptera: Gelechiidae) on greenhouse tomatoes in southern 0 ntario and its control using mating disruption. Proc. Entomol. Soc. O ntario 128:93-98.

Weaver, D.B., R. Kabana Rodriguez, and E.L. Carden. 1998. Velvetbeen and bahiagrass as rotation cropsfor management of $\mathrm{M}$ eloi dogynespp. and $\mathrm{H}$ eterodera glycines in soybean. J. N ematol. 30(suppl):563-568.

Wyland, L.J., L.E. J ackson, and K.F. Schulbach. 1994. Soil-plant nitrogen dynamics following incorporation of a mature rye cover crop in a lettuce production system. J. Agr. Sci. Cambridge 124:17-25. 